\title{
Reviving Cultural Tourism in Kendran Bali Indonesia: Maintaining Traditional Architecture and Developing Community-based Tourism
}

\author{
I Dewa Gede Agung Diasana Putra", I Made Adhika, Anak Agung Gde Agung Yana \\ Department of Architecture, Faculty of Engineering, Udayana University, 80361, Bali, Indonesia
}

Received December 17, 2020; Revised January 28, 2021; Accepted February 24, 2021

\section{Cite This Paper in the following Citation Styles}

(a): [1] I Dewa Gede Agung Diasana Putra, I Made Adhika, Anak Agung Gde Agung Yana, "Reviving Cultural Tourism in Kendran Bali Indonesia: Maintaining Traditional Architecture and Developing Community-based Tourism," Civil Engineering and Architecture, Vol. 9, No. 2, pp. 328 - 338, 2021. DOI: 10.13189/cea.2021.090206.

(b): I Dewa Gede Agung Diasana Putra, I Made Adhika, Anak Agung Gde Agung Yana (2021). Reviving Cultural Tourism in Kendran Bali Indonesia: Maintaining Traditional Architecture and Developing Community-based Tourism. Civil Engineering and Architecture, 9(2), 328 - 338. DOI: 10.13189/cea.2021.090206.

Copyright $\bigcirc 2021$ by authors, all rights reserved. Authors agree that this article remains permanently open access under the terms of the Creative Commons Attribution License 4.0 International License

\begin{abstract}
As a tourist destination, traditional villages and houses are not only places for socio-cultural and domestic practices but also facilities for tourists. This phenomenon is a paradox in the development of a cultural tourism area. Tourists expect a natural and authentic culture. On the other hand, the community hopes to participate actively in tourism activities and utilize their houses and village as economic resources. The participation of local people plays a vital role so that the success of developing a tourism destination depends on the level of the local communities' supports. However, people's participation in the tourism business has triggered local culture transformation since they have utilized their traditions, including their vernacular house and village, as tourist resources. To investigate this phenomenon, architectural examination and interviews are used as a method of investigation. This paper found that to sustain the tourism destination, it is significant to pay attention to its planning and traditional house transformation. In the transformation process, local communities must be encouraged to identify their own goals so that the development of tourism in the village can address tourist needs without polluting the traditional values. This participation model discusses the relationship between local traditions and practices, including traditional building practices and tourism. This model can be implemented in other tourism villages.
\end{abstract}

Keywords Pre-historic, Community's Participations,
Collaboration, Cultural Tourism, Transformation

\section{Introduction}

Bali, Indonesia's tourist destination, highlights its culture as a tourist magnet. However, there are two possible types of tourism in Bali, namely sunlust and wanderlust [1]. The first is tourists' eagerness to rest, relax and the three 's': "sun, sea and sand" [2, p. 33]. Secondly, some visitors want to tour and experience various cultures and interact with local people. This model brings cultural experiences to tourists interested in cultural forms, such as religious shrines, markets, ceremonies, heritage buildings and sites in their natural environment [3]. This model of tourism type is called "tours of living culture" [3, p.575], in which cultural activities are not staged for tourists, but they can often witness and experience the traditional festivals in houses, temples and village facilities.

A tourism village called desa wisata is one kind of tourism development generated by Bali's government to develop and increase the economic condition of people in rural areas of Bali. This model is tourist activities in a village that emphasize and rely on the attractiveness of rural life. A village can be developed as a tourist village if the village still has socio-cultural traditions and practices 
relatively preserved [4]. A tourist village is composed of various factors, especially related to the village's uniqueness and the existence of community groups that actively participate in maintaining their culture [5].

This tourism model is potentially supported by tourists' motivation to witness socio-cultural practices in other regions. This motivation is supported by the sense of touristic curiosity, involving the motivation to search for others' community identities and cultures [6]. However, the tourists' curiosity of local culture and the interaction between tourists and local culture and communities are vulnerable to cultural distraction since culture is one of the fragile tourism components [7], [8]. In this term, residential vernacular architecture is one of the cultural artefacts that drive the tourists' curiosity motives.

Many tourists want to explore the physical setting of the traditional residential architecture, including its occupants' traditional practices. The residential architecture concerning settlement pattern and environmental landscape is a visible and impressive object that presents local cultural identity [6] in which this residential architecture, reflecting the lifestyle and the culture of a community [9], becomes an attraction for tourists.

Although the participation of local people in tourism activities is essential for the success of developing a tourism destination, the interaction has the potential to transform the local culture and traditions. Many popular tourist villages in Bali, such as Ubud, Sanur, and Kuta, have experienced transformations in which new structures have been built in the rice fields around the village and traditional house by demolishing the old, adjacent to existing buildings, in front of the compound or a backyard [10], [11]. The construction of new buildings is potentially the severe practice of changing the setting, forms and spaces of the villages and residential architecture that are an architectural identity. This identity is a tourist attraction asset. Based on these experiences, can the village of Kendran develop cultural tourism without polluting local culture? This phenomenon is a challenge for local people to revive cultural tourism by maintaining their identity while adding new functions in their village and houses as tourist facilities. These two conflicting agendas of the village and houses show the ongoing discussions about the impacts of tourism on the local culture. The new agenda of the residential architecture generates tension in preserving the continuity of Balinese culture.

\section{Cultural Tourism Village and Community-based Tourism Development}

A tourism village called desa wisata is a tour to enjoy the beauty of natural conditions and rural community life. Traditions and the daily life of a community are resources that are attractive to tourists [12]. In this tourism model, a group of tourists lives in local communities or remote villages to enjoy and get new experiences of traditional village life and the local environment [13]. This model integrates attractions, accommodation and traditional facilities that are presented in a structure of community daily life that integrates with applicable procedures and traditions [14].

Since this tourism model uses local people's private properties, local communities' participation is an essential aspect [15]-[17] in which it is strongly associated with cultural tourism. Cultural tourism is travelling activities to visit certain places with cultural motivation to enjoy cultural artefacts, attractions, local people's daily life, and local festivals [18]. Therefore, to support this cultural tourism, many tourist destinations endorse and attempt to maintain their culture and traditions as main assets to get travellers' attention. The development of cultural tourism in a traditional village is defined as efforts to complement and enhance tourism facilities to meet tourists' needs [19]. Local people play important roles because the resources, unique traditions and culture inherent in these communities are the main driving elements so that the success of developing a tourism village depends on the level of acceptance and supports of the local community in which this model is called community-based tourism (CBT) [20]. On the other hand, local communities that grow and live side by side with tourist attractions become a part of an interlinked ecological system.

Community participation is an essential component to grow independence and the empowerment process [21]. People in a community involve making the decision process until implementing the attraction and tourism program [22]. However, the participation is also important to include stakeholders, including the government, the private sector, and other community members [22]. Local communities' involvement is essential to accommodate the desires and abilities of local communities to participate and obtain maximum value from tourism development. Local community participation is needed since the local community is the owner of tourism resources offered to tourists.

\section{Method}

This paper presents a case study of Kendran village as a tourism village in Gianyar Bali. A particular kind of pre-historic artefacts, natural environment, traditional village and the residential vernacular compound house is represented in this village. These elements become components of the development of tourism villages in Bali. Therefore, this paper investigates the tangible and intangible cultural heritage and environment of Kendran, 
including its traditional architecture. Architectural analysis and spatial stories of people's practices are a method of investigation. This method elaborates architectural documentation, graphical analysis and narratives of people's socio-cultural practices.

\section{The Emergence of Tourist Village of Kendran}

Kendran Village, the neighbour village of Ubud, is about $30 \mathrm{~km}$ northeast of Denpasar, the capital of Bali. It rises to an altitude of 450-600 $\mathrm{m}$ above sea level. The village is surrounded by rice fields punctuated by hills and gorges. The farmsteads in Kendran were traditionally built by utilizing local building materials and methods.

Historically, Kendran has been a centre of settlements since the IV century, where the village was the centre of blacksmith's activity. This activity can be predicted by discovering four pieces of a stone casting mould as casting for a drum called nekara or moko (Figure 1), around Manuaba [23]. This evidence presents that metal manufacture and production have already occurred in Bali during the Early Metal period [23]-[25].

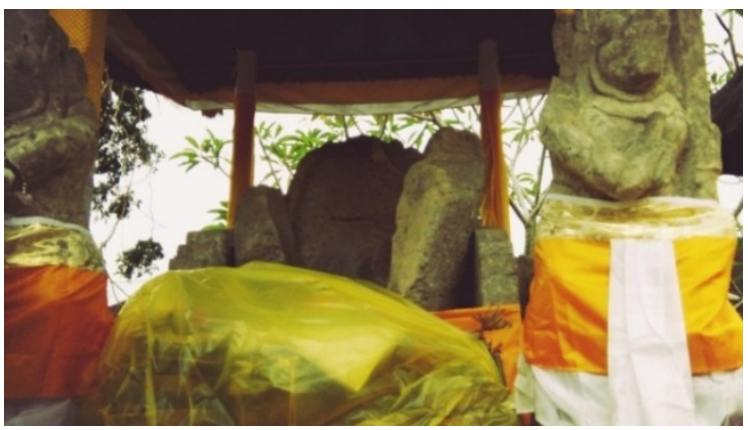

Figure 1. The pieces of a stone casting mold in Pura Desa Manuaba Kendran

The discovery of some sarcophagi (Figure 2) also supports the prediction that this village was the cultural centre of an ancient settlement area. The sarcophagi are oriented toward the mountain or high land [25] called kaja in which this direction is believed as a place of God and the final destination of the souls [26], [27]. This orientation concept has still been implemented in Bali as the orientation of the settlement and house [28]. Meanwhile, the existence of several holy springs and fountains, called petirtan with niches, shows that the village, especially around the fountain of Telaga Waja, was a place of hermitage and meditation (Figure 3).
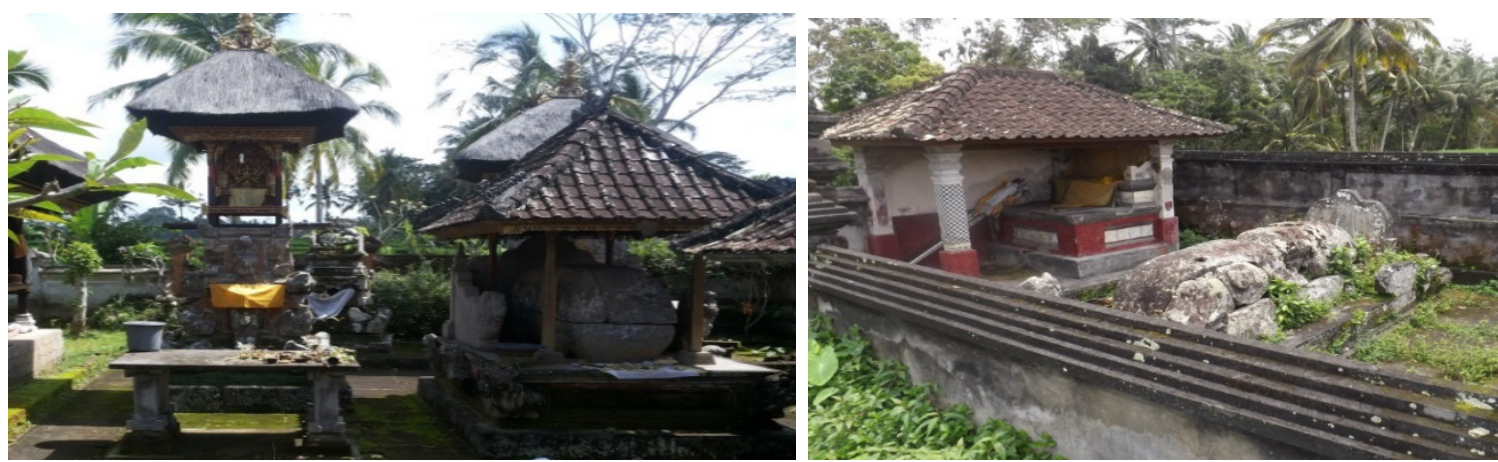

Figure 2. Sarcophagi in Kendran

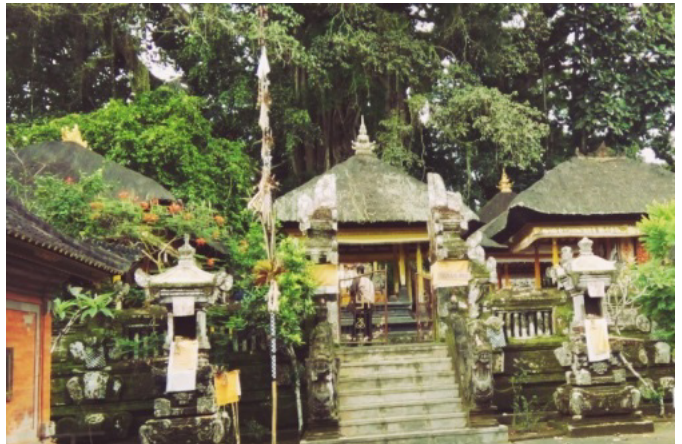

a. Griya Sakti Manuaba Temple

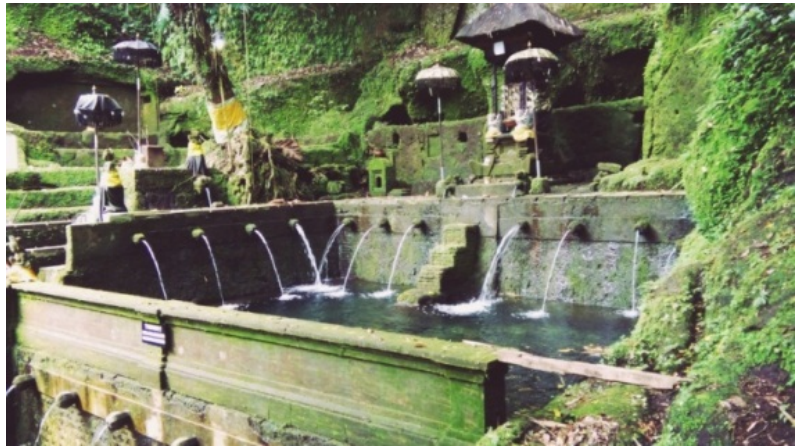

b. The fountain of Telaga Waja

Figure 3. Griya Sakti Manuaba Temple (Figure 3a) and the fountain of Telaga Waja (Figure 3b) 
The settlement and village pattern is predicted to be influenced by the orientation of the sarcophagus, where the head is in the more sacred area ( $k a j a)$ and the legs are in the more profane area (kelod). This orientation is related to the religious orientation inspired by Balinese Hindu philosophy in which kaja (toward to high place) is the sacred direction, while kelod is the opposite direction meaning the seaward that is less sacred and tends to be impure [29]. In general, this orientation produces a linear pattern in which the road is the primary orientation where all village facilities, including their settlements, face this central core.

On the other hand, the residential vernacular architecture in Kendran, as other residential architecture in Bali, using sanga mandala concept. Sanga mandala is a cosmological hierarchy concept that organizes a spatial pattern, including a house into nine zones [30], [31]. In this pattern, the house is organized based on the occupant activities so that socio-cultural activities can be performed, including the courtyard called natah (Figures 4) and many pavilions called bales (Figures 5). A courtyard in many communities is very popular because it has many functions and benefits for the occupants [32]. On the other hand, in the backyard, people raise animals and plant any vegetation. The house is arranged to accommodate the procession of ritual and ceremonial practices [33].

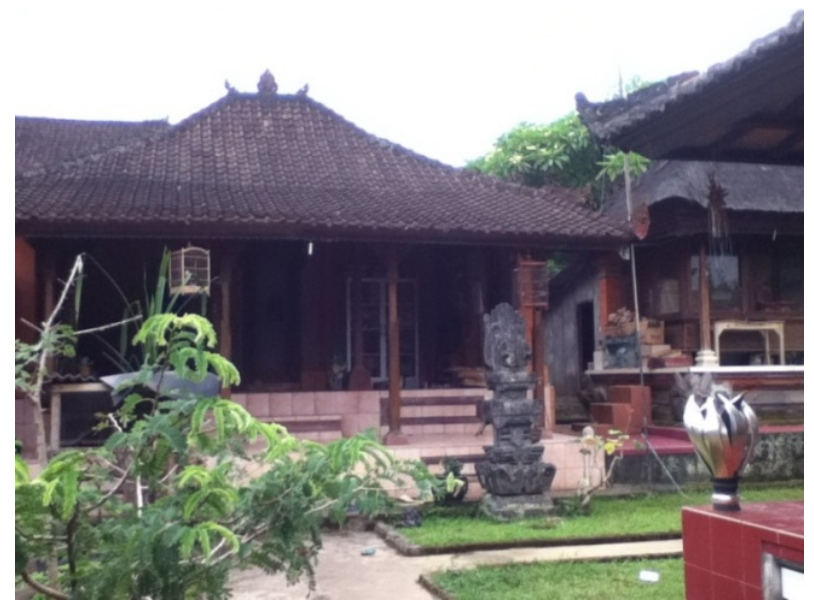

Figure 4. Natah, the courtyard in the traditional Balinese house

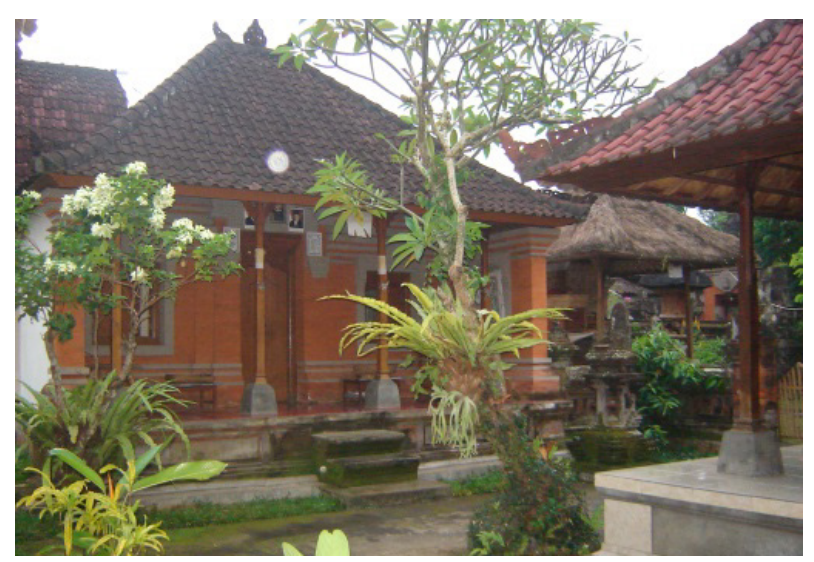

Figure 5. A pavilion in the traditional Balinese house

\section{Developing Cultural Tourism of Bali}

The mentioned beautiful sceneries are very popular as a vacation place for tourists. The nature of its original settlement structure, various unique relics from the pre-historic era and the residential vernacular architecture make this village is potent to be visited by tourists. Therefore, people believe that maintaining their culture and custom is to demonstrate their honour to God and their ancestors by performing religious practices in temples that consist of many shrines and pavilions, including meru, the symbol of a mountain [34]. In their belief, maintaining their culture and traditions is the way to present their respect to God and ancestors. So that way, the main problem in the development of tourism activities in a tourist village is a conflict between maintaining traditional values and the insertion of new tourism functions. These also challenge local people to provide economic benefit without overriding its cultural function both as a traditional economic function and protecting the environment and local culture.

To be successful in cultural tourism, community-based tourism (CBT) becomes a public tourism policy and a model of sustainable tourism development in tourism [20]. Tourism destination communities are also involved and play a major role in shaping tourism figures and identity. This approach places a greater priority on involving local stakeholders in the tourism planning and development process. In the implementation of CBT indicator, based on the ASEAN Community Based Tourism Standard, community ownership is one of the important aspects, including the contribution to well-being [35]. This aspect is related to the effort to produce and maintain a healthy economy and local communities' welfare. In order to produce the welfare of local communities, the diversification of tourism activities and facilities is needed. These cultural artefacts and activities become the destination community's assets and resources. These resources are a public good that is the people and stakeholders can share the benefit in the local destination. The benefit of public good involves external consumption effects to the community members. Therefore, it is not easy to get support from local people to finance additional facilities [36].

The government will handle and finance the village infrastructure and facilities [37]. Therefore, government and other tourism stakeholders have also had important roles supporting the CBT Development in a cultural tourism destination. The collaboration between residents and the government becomes a delicate task for local authorities to maintain both sides' needs and wants to ensure the sustainability of tourism development in the village [38]. The government and local community have to work together to plan, implement and manage tourist facilities in a tourism destination. On the other side, 
tourism stakeholders also have a responsibility to maintain public and tourist facilities. The stakeholders have to support communities to plan and build any tourism facilities to support the facilities that are built by local communities and government. However, stakeholders' constructions have to be discussed with local communities to maintain the local cultural component of the tourist destination.

Preservation cultural aspects are the other important components in the development of cultural tourism development. This aspect keeps the healthy culture of the tourist destination, including maintaining cultural integrity and enriching the values of the local cultural traditions [35]. Therefore, local communities have to preserve and are proud of their culture, including the traditional houses and village. Traditional houses and village facilities, which have additional functions accommodating tourist activities, are arranged in a proper approach to avoid the erosions of their traditional and cultural value. The people have tried to preserve the main house tasks as a place for socio-cultural and domestic activities. The traditional gate called angkul-angkul, a small wall behind the angkul-angkul called aling-aling, the plot walls called tembok pekarangan and telajakan (space between a front plot wall and a road) are local building apparatuses that present the figure of the local village pattern and image. The presence of these elements presents the traditional house's authenticity [11], [39]. Moreover, the alignment of these elements along the village road adds to the traditional impression's strength.

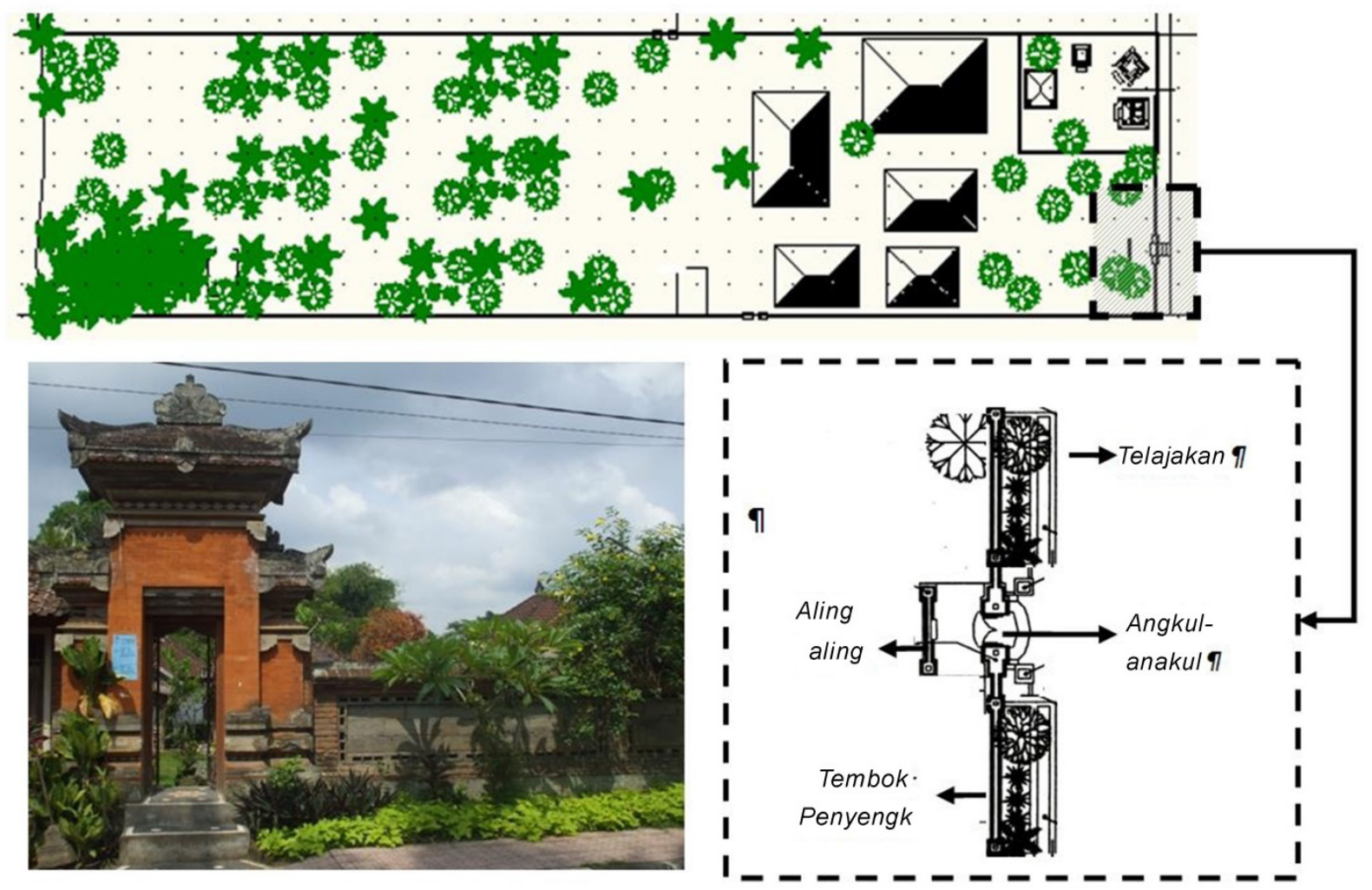

Figure 6. Angkul-angkul (the traditional gate) and traditional walls in the traditional Balinese house 

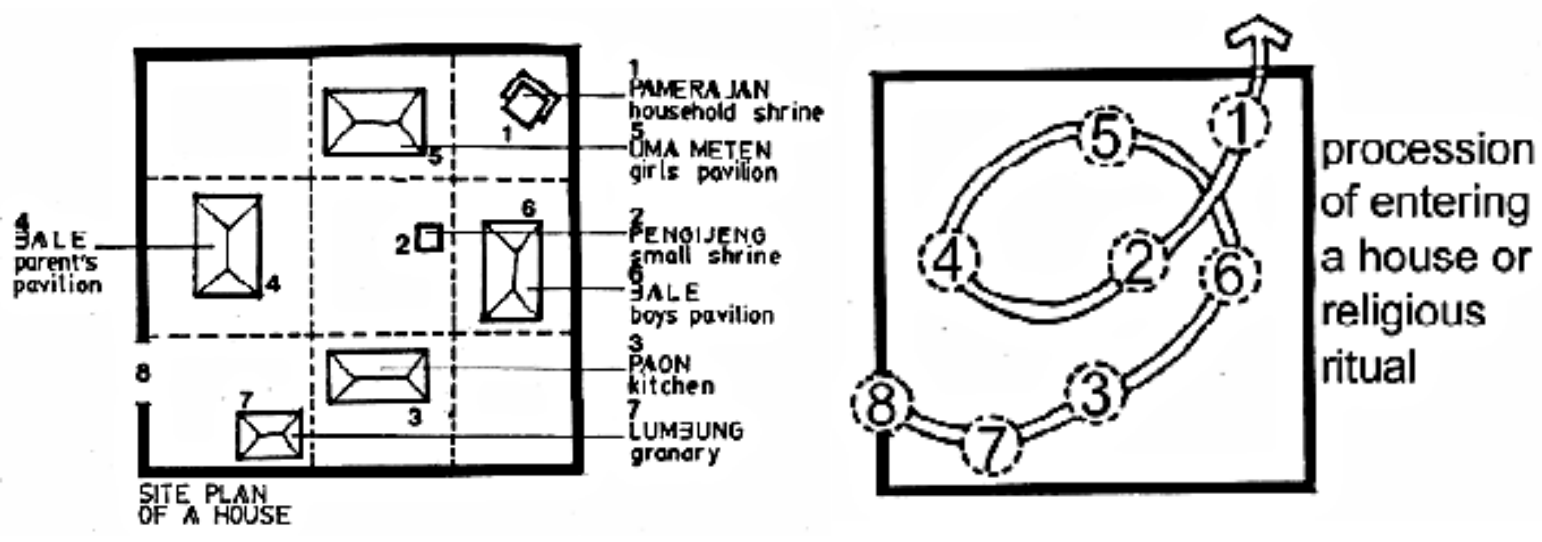

Source: Ferschin \& Gramelhofer 2004

Figure 7. Process of entering a house

However, some aspects of the houses are adjusted to address the tourist needs. Some approaches need to be taken to show the character as a traditional house both physically and philosophically. In order to persist and maintain the sustainability of the cultural tourism industry in the village, the setting of the traditional house can be adjusted to address the economic function of the house without avoiding its traditional values.

In a traditional house transformation, identifying the philosophy and concepts of the original setting is essential. The original concept of the hierarchy of entering the house, for example, should be recognized, so that the transformation still addresses the traditional values and meaning. In a traditional Balinese house, people through an angkul-angkul (8), a granary called jineng (7) and a kitchen called paon (3) before entering a courtyard called natah and pavilions, including the eastern pavilion called bale dangin (6), northern pavilion called bale daja (5), western pavilion called bale dauh (4) and the courtyard shrines (2)). Finally, the occupant can go to the family temple (1). The hierarchy demonstrates the order of activities and cultural spaces from domestic activities and spaces into ritual activities and spaces [40] (Figure 7).

The hierarchy presents that a paon (kitchen) is a central pavilion. Balinese routines start when mothers light the first fire for cooking in the kitchen and make animal food during the afternoon [41]. The kitchen is believed as a spiritual purification space. These purification activities are performed by the occupants when the people carry out a simple ritual after the occupants attend a funeral ceremony in other houses. This ritual is a way for occupants to avoid negative spirits and to be ready to enter other spaces or to continue other rituals in a ceremony. The kitchen location has a symbolic significance that people are spiritually cleansed before the occupants perform activities in the house. Therefore, the position of the kitchen is sought to remain in its position. By improving the physical condition and adapting to residents' needs, this kitchen can be used as a place for providing breakfast to tourists.

The northern pavilion (bale daja) and eastern pavilion (bale dangin) are not used as tourist facilities. Both pavilions are expected to still play an essential role in cultural activities and the residential spaces. While the northern and eastern pavilions have a religious role in the house, the western pavilion (bale dauh) is a bedroom. Since the pavilion is more for domestic activities, this pavilion can be transformed into tourist facilities by building additional structures such as bathrooms and lavatory (Figure 8). 


\begin{tabular}{|l|}
\hline $\begin{array}{l}\text { Additional structure for } \\
\text { supporting the bale dauh to } \\
\text { be tourist accommodation }\end{array}$ \\
\hline
\end{tabular}

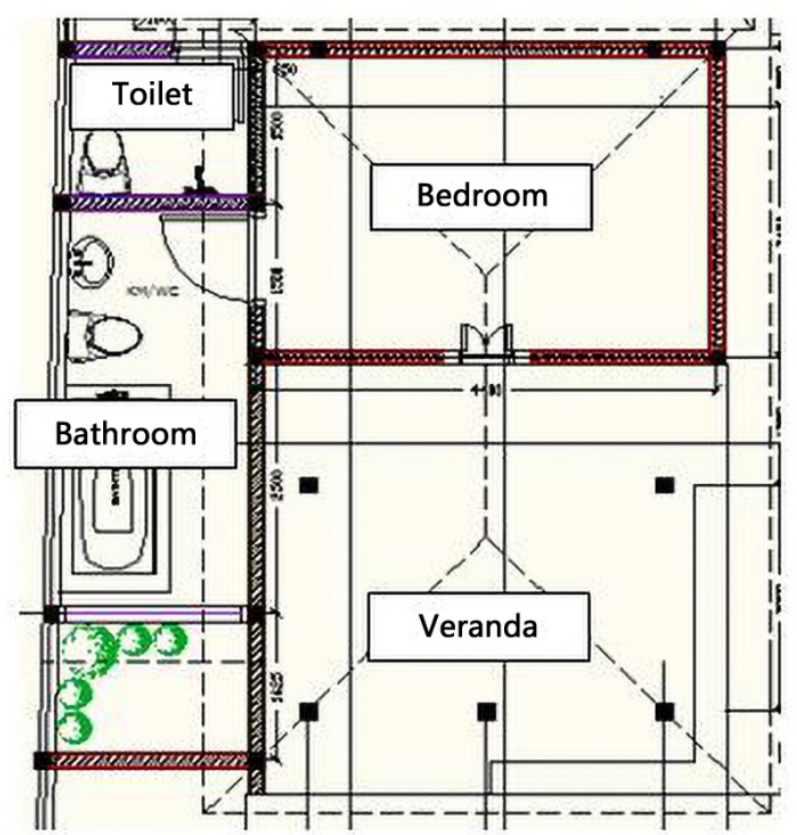

Figure 8. A model of the transformation of a pavilion for tourist accommodation

The construction of tourist accommodation is recommended in the backyard called teba by building tourist accommodation and other supported facilities such as the people in Ubud that used their traditional house as a homestay. In a traditional house of Ubud, the constructions pay attention to the building's density so that the backyard, ecologically and culturally, can still have its traditional functions. As an inseparable part of a Balinese house, the backyard called teba is the legs [41]. This part has an important function to provide materials for food and offerings. In the backyard, Balinese plant vegetation and raise animals and a place for preparations of ceremonies by constructing temporary buildings called tetaring. This simple construction is made from bamboo and coconut leaves in which bamboos are for structure and woven coconut leaves called klangsah are for the roofs.

A traditional house in Ubud that is used for a homestay, for example, consists of many spaces, including a family temple (1), some pavilions (2), (3), (5), a kitchen called paon (6) and a granary called jineng (7) (Figure $9 \mathrm{~A})$. In front of the house is a traditional gate (8). The owner has also built a rompok (10) to store agricultural tools in the backyard. A new pavilion was built near the kitchen (12)) and adjacent to the west pavilion called bale dauh to provide new rooms for tourists and the increase of occupant number. An art studio (14) was built next to the bale dangin (5) and a garage (15) was constructed by demolishing a part of the front wall. The owners also built tourist accommodations (13) in the teba (Figure 9B) that have transformed the backyard functions into gardens for tourist convenience. 


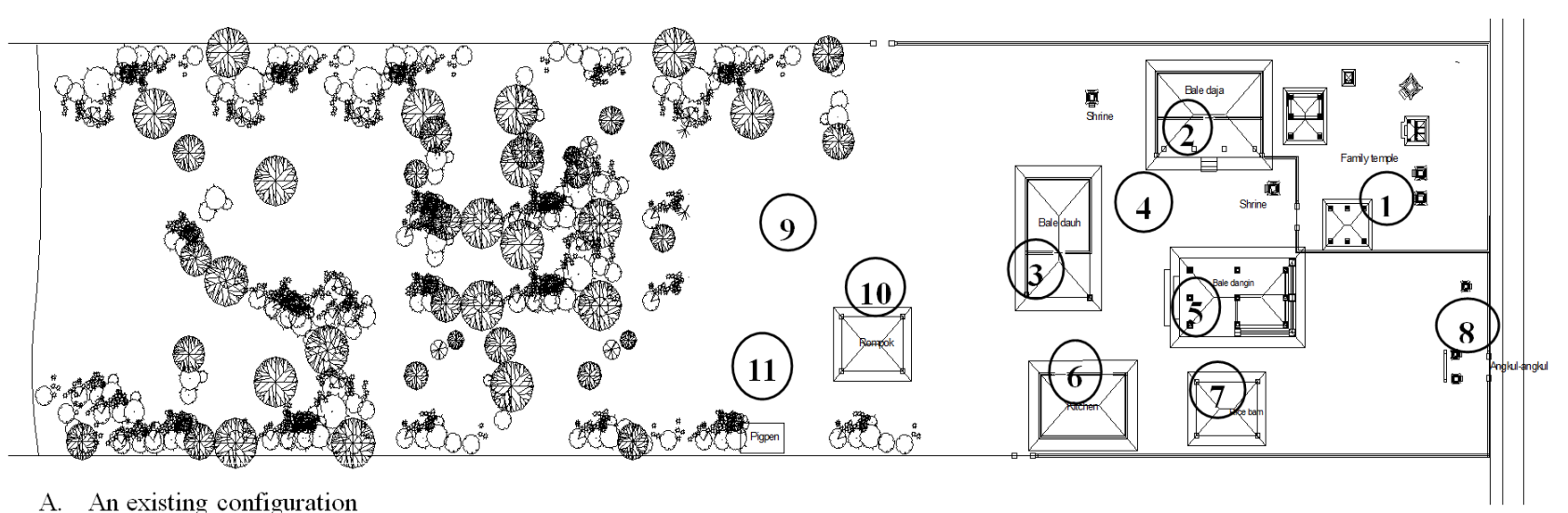

A. An existing configuration

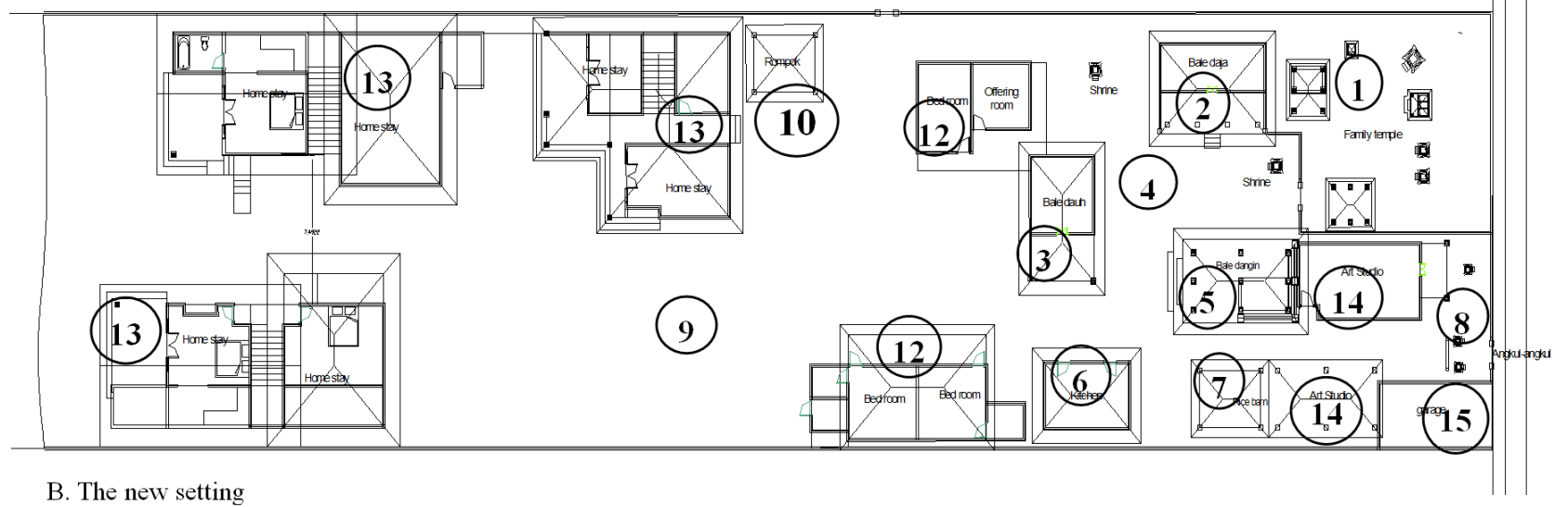

Figure 9. A model of the transformed traditional house

The abovementioned transformation of a traditional house in Ubud as an example presents the varied possibility of desires that can be satisfied through a flexible conception of spaces in the houses [42]. Based on Ubud's experiences, the house transformations in Kendran are also possible to become a strategy to accommodate tourist activities in the house and develop tourism products based on community-based tourism development. This effort supports the other efforts to develop a culture-based tourism village. It can be realized by developing existing tourism products and developing new products that are still related to previous products. Existing products can be packaged into more attractive tour packages, organized into a list of cultural events, making trekking and cycling tour packages, and designing activities with the community through living with local communities in a homestay managed by local people.

The cultural activities can be utilized as a tourism product in which a village is a place where many various activities are performed. Regularly, many cultural activities are carried out in temples in which these activities utilize spaces in the village. Many ceremonial practices are also carried out in the traditional house. Such activities become a cultural performance for tourist attractions.

Inseparable from the culture and part of the cultural landscape of Bali [43], the nature of the village can also be an essential resource to develop tourism products. This aspect is related to natural preservation, including conservation and improvement of the environment [35]. In this aspect, tourist activities in the natural environment become interesting activities for tourists. Trekking and cycling tour packages can be developed by utilizing the beautiful environment as a trekking or cycling path. Trekking paths can be taken for two to three hours and one hour for cycling. Tourists can choose to cycle around the village or stop to observe the activities provided by the community. Since the activities in the natural environment such as paddy fields, around rivers and agricultural fields, the local people have to maintain their natural condition to support tourist activities, because the pollution of the natural conditions is potent to decrease the number of tourists. Therefore, the natural environment and local people's agricultural life activities have become important aspects of being maintained to support CBT. These packages can be combined with the living with local community tour packages, including cooking class, traditional farming, traditional medicinal plants and making offerings. In this package, tourists can see, witness and be involved in the local people's daily lives both in the village and in the traditional Balinese house.

The interaction between local people and tourists also 
has the other important aspect of CBT to maintain tourist satisfaction. Tourists become get new experiences about local people traditions and practices. These activities have become interesting activities for tourists that keep tourists stay long in the village and come back again in other time with their friends. However, to maintain the tourist satisfactions, local people have to carry out the activities properly. Local people must be trained in many aspects of tourism hospitality. The development of tourist facilities in pre-historical artefacts should involve archaeology experts so that the constructions do not damage the historical value of the artefacts. The collaboration between residents, government, tourism agencies, academics and other parties becomes significant to develop tourism development sustainability.

Each element of the stakeholders must have good coordination and collaboration. Collaboration can be presented as "a process of joint decision making among key stakeholders of a problem domain about the future of that domain" [44]. However, this collaboration must be different from the hierarchically structured forms of the traditional organization in which such an organization usually does not adequately address the complex social issues [45]. In order to face the turbulence of the global issue, innovative organizational forms need to be established in a tourism destination. This innovative organization involves "key stakeholders and refining processes for joint decision-making on destination planning and management issues within a community-based domain" [38]. The community as the host must provide the best service while the government and other stakeholders should support the host by providing training activities and developing tourist infrastructure.

In this system, the government provided a study to design attractions in the village and the packages' routes. This study was also designed and developed infrastructures to support tourist activities such as pedestrian ways, parking areas, and receptionist offices. In this management system, the management of the tourism village should have rules regarding the construction of tourism facilities and the distribution of fees that are adjusted to local village rules called awig-awig. The preparation of this regulation needs to be discussed with the community in open meetings related to the progress or obstacles during the development process. In this system, the management needs to collaborate with the village in bringing practitioners or academics to revive art groups in the community by requiring extracurricular activities in each school regarding local culture (dance and percussion) to increase the knowledge and love of the younger generation towards history and culture in the village. The government continuously provides training/guidance to the community by inviting practitioners or academics to learn about tourism, market culture, understanding of local culture, and language skills.

\section{Conclusions}

Kendran has the opportunity to develop cultural-based tourism products using pre-historical artefacts, socio-cultural activities of the communities and the environment. Historically, the village has been a centre of settlements since the IV century, where many heritage historical artefacts still exist today. The traditional settlement and houses around the beautiful scenery still exist and have been used by the local people. These artefacts, cultural productions and the environment have been significant resources for tourism development. However, these beautiful sceneries for tourism development have not yet given economic benefits to the local people. Most tourist facilities in the village are managed by non-local people. In this case, local people have not been empowered to develop their village's potential as a tourism destination.

Well known as a cultural place since pre-historic Bali, Kendran has opportunities to be a cultural tourism destination in Bali. In cultural tourism, cultures, both tangible and intangible, become significant components as tourism products. The traditional house can be a part of tourism products. By transforming any parts of the house, the people get benefit from tourists and still perform their socio-cultural activities in the house. In this term, local communities act as the host and become important actors. By transforming their house, people must be encouraged to identify their own goals and direct the development of tourism to improve the fulfilment of their needs. This community-based tourism is needed because the people are the owner of tourism resources offered to tourists. The traditional house as a tourism product can be combined with other resources such as the pre-historic artefact, holy spring and natural landscape. These are a series of tourism products that can be packaged into tour packages. To create these aspects, the collaboration between residents, government, tourism agencies, academics and other parties is significant. This model for developing cultural-based tourism can contribute to studies about tourism and tradition and can also be adapted and designed for the tourism village in other locations.

\section{Acknowledgements}

Thank you to the owners of the traditional Balinese houses and the community leaders of Kendran village who were willing to take part in this study.

\section{REFERENCES}

[1] H. P. Gray, International travel--international trade. Heath Lexington Books, 1970.

[2] S. Heitmann, "Tourist behaviour and tourism motivation," 
Res. themes Tour., pp. 31-44, 2011.

[3] R. E. Wood, "International Tourism and Cultural Change in Southeast Asia Author ( s ): Robert E. Wood Published by: University of Chicago Press Stable URL : http://www.jstor. org/stable/1153688 REFERENCES Linked references are available on JSTOR for this article : Yo," vol. 28, no. 3, pp. $561-581,1980$.

[4] F. Zakaria and R. Suprihardjo, "Konsep Pengembangan Kawasan Desa Wisata di Desa Bandungan Kecamatan Pakong Kabupaten Pamekasan," J. Tek. ITS, vol. 3, no. 2, pp. C245-C249, 2014.

[5] S. Falak, L. M. Chiun, and A. Y. Wee, "Sustainable rural tourism: An indigenous community perspective on positioning rural tourism," Turiz. međunarodni Znan. časopis, vol. 64, no. 3, pp. 311-327, 2016.

[6] N. Wang, "Vernacular house as an attraction: illustration from hutong tourism in Beijing," Tour. Manag., vol. 18, no. 8, pp. 573-580, 1997.

[7] E. Cater, "Ecotourism in the third world: Problems for sustainable tourism development," Tour. Manag., vol. 14, no. 2, pp. 85-90, 1993.

[8] R. Scheyvens, "Ecotourism and the empowerment of local communities," Tour. Manag., vol. 20, no. 2, pp. 245-249, 1999.

[9] Y. Sokienah, "Aspects of sustainability in the design elements of traditional jordanian houses," Civil Engineering and Architecture, vol. 8, no. 6, pp. 1194-1201, 2020, doi: 10.13189/cea.2020.080604.

[10] I. D. G. A. D. Putra, M. Lozanovska, and R. Fuller, "From spiritualistic toward more pragmatic pattern: Re-ordering Balinese houses and viability of the household traditions in tourism economy," J. Archit. Urban., vol. 43, no. 1, 2019 , doi: 10.3846/jau.2019.3692.

[11] I. D. G. A. D. Putra, M. Lozanovska, and R. J. Fuller, “A methodology to evaluate the transformation of traditional balinese houses as a consequence of Tourism," Archnet-IJAR, vol. 11, no. 1, 2017, doi: 10.26687/archnet-ij ar.v11i1.1134.

[12] R. G. Soekadijo, “Anatomi pariwisata," Gramedia Pustaka Utama. Jakarta, 2000.

[13] E. Inskeep, Tourism planning: an integrated and sustainable development approach. Van Nostrand Reinhold, 1991.

[14] W. Nurhayanti, Heritage, Tourism and Local Communities. Yogyakarta: UGM Press., 1999.

[15] D. Kala and S. C. Bagri, "Barriers to local community participation in tourism development: Evidence from mountainous state Uttarakhand, India," Turiz. međunarodni Znan. časopis, vol. 66, no. 3, pp. 318-333, 2018.

[16] D. P. O. Prasiasa, Destinasi Pariwisata Berbasis Masyarakat. Penerbit Salemba Humanika, 2013.

[17] M. Vučković and M. Maruna, "Notes on the development of the urban heritage management concept in contemporary policies," Spatium, pp. 42-50, 2018.

[18] W. T. Organisation, World Tourism Barometer, vol. 10. 2012.
[19] D. Pearce, "Tourism a Community Approach. 2nd: Harlow Longman.” Washington. DC (US): Island Press, 1995.

[20] S. Wearing and M. McDonald, "The development of community-based tourism: Re-thinking the relationship between tour operators and development agents as intermediaries in rural and isolated area communities," $J$. Sustain. Tour., vol. 10, no. 3, pp. 191-206, 2002.

[21] W. Adiyoso, Menggugat Perencanaan Partisipatif dalam Pemberdayaan Masyarakat. PMN, 2009.

[22] D. J. Timothy, "Participatory planningA view of tourism in Indonesia," Ann. Tour. Res., vol. 26, no. 2, pp. 371-391, 1999.

[23] I. W. Ardika, "Bronze artifacts and the rise of complex society in Bali," 1987.

[24] H. R. van Heekeren, Proto-historic sarcophagi on Bali. Dinas purbakala (Archaeological service of the Republic of Indonesia), 1955.

[25] Soejono, The distribution of types of bronze axes in Indonesia. Archaeological Institute of the Republic of Indonesia, 1972.

[26] J. Swellengrebel, "Introduction," in Bali: studies in life, thought, and ritual, J. Swellengrebel, Ed. Nethelands: Foris Publication Holland, 1984, pp. 1-76.

[27] R. Goris, "The religious character of the village community," Bali Stud. Life, Thought Ritual. Dordr. Foris Publ., 1960.

[28] I. G. N. Bagus, Sistem pola menetap masyarakat Bali. Denpasar: Fakultas Sastra Universitas Udayana., 1965.

[29] F. Eiseman Jr, Sekala and niskala: essays on religious, ritual and art, vol. I. Singapore: Periplus Editions, 1989.

[30] E. Budihardjo, "Architectural conservation in Bali," 1986.

[31] I. N. Gelebet, Arsitektur Tradisional Bali (Balinese Traditional Architecture). Denpasar: Bappeda Bali, 1998.

[32] G. Gangwar and P. Kaur, "User's perception of the relevance of courtyard designs in a modern context: A case of traditional pol houses, Ahmedabad," Civil Engineering and Architecture, vol. 8, no. 3, pp. 379-389, 2020, doi: 10.13189/cea.2020.080323.

[33] M. Hobart, "The path of the soul: the legitimacy of nature in Balinese conceptions of space," Nat. Symb. south east Asia, pp. 5-28, 1978.

[34] N. K. A. Dwijendra, "Meru as a hindu sacred building architecture with a high roof and resistant to earthquakes in Bali, Indonesia," Civil Engineering and Architecture., vol. 8 , no. 3, pp. 350-358, 2020, doi: 10.13189/cea.2020.080319.

[35] The ASEAN Secretariat, Asean Community Based Tourism Stadard. Jakarta: Association of Southeast Asian Nations, 2016.

[36] P. T. Long, R. R. Perdue, and L. Allen, "Rural resident tourism perceptions and attitudes by community level of tourism," J. Travel Res., vol. 28, no. 3, pp. 3-9, 1990.

[37] L. R. Allen, H. R. Hafer, P. T. Long, and R. R. Perdue, "Rural residents' attitudes toward recreation and tourism 
development," J. Travel Res., vol. 31, no. 4, pp. 27-33, 1993.

[38] T. B. Jamal and D. Getz, "Collaboration theory and community tourism planning," Ann. Tour. Res., vol. 22, no. 1, pp. 186-204, 1995.

[39] I. D. G. A. D. Putra, I. B. G. Wirawibawa, and M. W. Satria, "Spatial orientation and the patterns of the traditional settlement in the eastern Bali: Investigating new tourism atractions," Geojournal of Tourism and Geosites, vol. 29, no. 2, 2020, doi: 10.30892/gtg.29218-493.

[40] P. Ferschin and A. Gramelhofer, "Architecture as information space," Proc. Int. Conf. Inf. Vis., vol. 8, no. August 2004, pp. 181-186, 2004, doi: 10.1109/iv.2004.132 0142 .
[41] M. Covarrubias, Island of Bali. Tuttle Publishing, 2015.

[42] Đ. Alfirević and S. S. Alfirević, "Spatial organisation concepts for living spaces with two centres," Spatium, pp. 17, 2019.

[43] I. M. Adhika and I. D. G. A. D. Putra, "Reinvigorating cultural landscapes for planning cultural tourism in Bali," Geojournal of Tourism and Geosites, vol. 33, no. 4, pp. 1462-1469, 2021, doi: 10.30892/gtg.334sp103-594.

[44] B. Gray, "Collaborating: Finding common ground for multiparty problems," 1989.

[45] D. R. Austrom and L. J. Lad, "Problem-Solving Networks: Towards a Synthesis of Innovative Approaches to Social Issues Management," in Academy of Management Proceedings, 1986, vol. 1986, no. 1, pp. 311-315. 